\title{
Production Of Bioethanol From Corncob And Sugarcane Bagasse With Hydrolysis Process Using Aspergillus niger and Trichoderma viride
}

\author{
Dimas Sultan Syawala ${ }^{1}$, Tatik Wardiyati ${ }^{2}$, Moch. Dawam Maghfoer ${ }^{2}$ \\ ${ }^{I}$ Graduate School of Plant Science, Faculty of Agriculture, Brawijaya University, Jl. Veteran Malang 65145, \\ East Java, Indonesia. \\ ${ }^{2}$ Faculties of Agriculture, Brawijaya University, Jl. Veteran Malang 65145, East Java, Indonesia.
}

\begin{abstract}
Abstrack : Bioethanol is an alternative fuels derived from biomass that is more environmentally friendly and renewable. Corncob and sugarcane bagasse are a potential agricultural wastes used as raw material for bioethanol because it has a high carbohydrate content and abundant availability. The efforts to increase bioethanol production performed by enzymatic hydrolysis method using fungus cultures of Aspergillus niger and Trichoderma viride. This study aims to determine the best combination of the addition of A. niger and T. viride cultures on corncob and sugarcane bagasse raw materials which produces optimal bioethanol production with high substrate efficiency and low residual sugars content. The results showed that the use of corncob raw materials with the addition of Aspergillus niger culture is the best treatment combination that produces ethanol at 282,3 $\mathrm{ml} / \mathrm{kg}$ with 90,35\% substrate efficiency. While the bagasse raw material, the addition of Trichoderma viride culture is the best treatment combination that produces ethanol at 299,2 ml/kg with 90,95\% substrate efficiency.
\end{abstract}

Keyword: Bioethanol, hydrolysis, Aspergillus niger, Trichoderma viride, fermentation

\section{Introduction}

The use of fossil fuels contributes for a very large air pollution, which transportation sector contributes about $80 \%$ of $\mathrm{CO}_{2}$ emissions in atmoster. Bioethanol $\left(\mathrm{C}_{2} \mathrm{H}_{5} \mathrm{OH}\right)$ is an ethanol produced from biomass or natural raw materials through fermentation of sugar with the help of microorganisms, such as yeast. Bioethanol is a fuel that is more environmentally friendly and renewable.

Some species of plants have been investigated for bioethanol production, such as cassava, sugarcane, corn and waste products of agriculture (Muthuvelayudham and Viruthagiri, 2007). Potential agricultural waste used as bioethanol raw materials are corncob and sugarcane bagasse. Corncob has a high carbohydrate content and is able to produce ethanol at 0,358 liter $/ \mathrm{kg}$ dry mass. While bagasse can produce ethanol at 0,279 liter $/ \mathrm{kg}$ dry mass (Kuhad and Singh, 1993).

Bioethanol production process generally consists of four steps, namely the process of material preparation or pretreatment, hydrolysis, fermentation and distillation. Hydrolysis process is an important step because it determines the amount of glucose produced as a substrate to be fermented into ethanol. Hydrolysis process can be carried out with an acid catalyst, the catalyst combination of acid and enzymes, as well as the catalyst enzyme and enzyme (Muthuvelayudham and Viruthagiri, 2007; Patel et al., 2007).

Bioethanol production is still not optimal. One is because the saccharification process only lasts for destruction by the heating process, so that the amount of sugars produced is not optimal. The efforts to increase the production of bioethanol can be done by using a cellulolytic fungus culture in the process of hydrolysis of lignocellulose by enzymatic hydrolysis method. Lignocellulose degrading enzymes are cellulase and hemicellulase. Some groups are often utilized cellulolytic fungus in lignocellulose degradation are Aspergillus niger and Trichoderma viride (Prasad et al., 2009; Tribak et al., 2002). Both of this fungus consist of three classes of cellulase enzymes that endoglucanases, celllobiohydrolases and $\beta$-glucosidases (Juwaied et al., 2011). Cellulase enzyme activity produced by A. niger and T. viride is higher compared with the other fungus, namely A. nidulans, A. terreus, A. wentti, T. reesei, T. koninigii and T. linqnorum (Juwaied et al., 2011). The purpose of this research is to determine the best combination of the addition of culture Aspergillus niger and Trichoderma viride on corncob and sugarcane bagasse raw materials which produces optimal bioethanol production and high substrate efficiency with low residual sugar content.

\section{Materials And Methods}

2.1Tools and materials

Materials that used in the bioethanol production are corncob, sugarcane bagasse, fungus cultures (Aspergillus niger and Trichoderma viride) and yeast (Saccharomyces cerevisiae). Chemical materials in the 
pretreatment and hydrolysis process using $\mathrm{NaOCl} 0,15 \mathrm{~N}, \mathrm{NaOH} 2 \mathrm{~N}, \mathrm{HCl} 0,5 \mathrm{~N}, \mathrm{Na}_{2} \mathrm{CO}_{3} 2 \mathrm{~N}$, aquadest, ammonium sulfate, peptone, PDA and YMGP. The tools used in the production and analysis of bioethanol are; oven, autoclaf, analytical balance, $\mathrm{pH}$ meter type 900 IT WalkLAB, haemocytometer, Picnometer, Gas Chromatography (GC) and Rotary vacuum evaporator type Heidolph.

\subsection{Research methods}

This research using randomized complete design with eight treatments and three replications. Observed factors are the type of raw materials and the addition of culture Aspergillus niger and Trichoderma viride on the hydrolysis process. The first factor is the type of bioethanol raw materials, namely corncob and sugercane bagasse. The second factor is the addition of fungus culture in the hydrolysis process, namely: Without fungus addition, with the addition of Aspergillus niger culture, with the addition of Trichoderma viride culture and with the addition of combination cultures of Aspergillus niger + Trichoderma viride.

\subsection{Pretreatment}

First step delignification corncob and sugarcane bagasse materials that had been ground to a size of 60 mesh. The first is done by soaking the delignification of 500 grams of each materials using $\mathrm{NaOCl} 0,15 \mathrm{~N}$ at room temperature for five hours with a ratio of 1: 8 (materials: solvent). Second delignification using $\mathrm{NaOH} 2 \mathrm{~N}$ at room temperature for 24 hours with a ratio of 1: 4 (materials: solvent). The result are corncob and sugarcane bagasse powder.

\subsection{Acid and enzimatyc hydrolysis}

Hydrolysis method using acid and enzymatic hydrolysis. The first step, delignified corncob and sugarcane bagasse from each of the added water with weight ratio of 1: 5 (powder: water). $\mathrm{HCl} 0,5 \mathrm{~N}$ was added to adjust the acidic conditions ( $\mathrm{pH} \pm 4,5$ ). Substrate hydrolyzed by heating at a temperature of $115^{\circ} \mathrm{C}$ for 60 minutes using autoclave. The next sep, the hydrolyzate was added $10 \%(\mathrm{v} / \mathrm{v})$ culture of Aspergillus niger and Trichoderma viride in accordance with each treatment. For the combination treatment of Aspergillus niger + Trichoderma viride, the amount added is respectively $5 \%(\mathrm{v} / \mathrm{v})$ from each Aspergillus niger and Trichoderma viride. Hydrolysis performed at room temperature for 72 hours. Furthermore, the results of hydrolysis neutralized with $\mathrm{Na}_{2} \mathrm{CO}_{3} 2 \mathrm{~N}$ until $\mathrm{pH} \pm 6$.

\subsection{Preparation of fungus and yeast culture}

Aspergillus niger and Trichoderma viride cultured in PDA (Potato Dextrose Agar) were made in test tubes and grown in an incubator at a temperature of $28^{\circ} \mathrm{C}$ for 7 days. Saccharomyces cerevisiae yeast isolates rejuvenated on PDA and incubated for 2 days. Furthermore, isolates were grown again in $50 \mathrm{ml}$ of YMGP media consisting of yeast extract $5 \mathrm{~g} / \mathrm{l}$, malt $5 \mathrm{~g} / \mathrm{l}$, glucose $10 \mathrm{~g} / \mathrm{l}$ and peptone $5 \mathrm{~g} / \mathrm{l}$ in $200 \mathrm{ml}$ erlenmeyer. Incubation was performed at $30^{\circ} \mathrm{C}$ for 24 hours.

\subsection{Fermentation and distillation}

Fermentation takes place in anaerobic conditions. Substrate hydrolysis of each materials added to $1 \mathrm{~g} / \mathrm{l}$ peptone and $4 \mathrm{~g} / \mathrm{l}$ ammonium sulfate as nutrients. Then added yeast Saccharomyces cereviciae culture as much as $10 \%(\mathrm{v} / \mathrm{v})$. The fermentation process lasts for seven days. During the fermentation process the $\mathrm{pH}$ value, total sugar and ethanol content were analyze. After eight days, filtered fermented, then distillation to separate the ethanol from the water fraction of the substrate fermentation at a temperature $78-80{ }^{\circ} \mathrm{C}$ using Rotary vacuum evaporator.

\subsection{Analysis of fiber composition}

Analysis of fiber include cellulose, hemicellulose and lignin content, performed on the material before and after delignification process (pretreatment), and substrate hydrolysis residues.

\subsection{Analysis of reducing sugars and total sugars content}

Reducing sugar content was analyzed by the method of DNS, while the total sugar content was analyzed by the method phenol. Reducing sugar analysis performed on substrate hydrolysis. While total sugar analysis performed during the fermentation process every 24 hours.

\subsection{Analysis of ethanol content}

Analysis of ethanol content (\% v/v) was performed on the fermentation process, measured using Gas Chromatography (GC) and picnometer. Observations made during the ethanol fermentation process every 24 hours until the end of the fermentation process. 


\subsection{Ethanol yield}

Ethanol extracts obtained from the separation by distillation which has been separated from the water. Measured volume of ethanol obtained from 500 grams of dry mass.

\subsection{Substrate efficiency}

Substrate efficiency is the percentage concentration of substrate (total sugars) are consumed for the production of the initial substrate concentration used in the production. The amount of substrate consumed is the difference between the initial concentration of total sugar (So) with the concentration of sugar at the end (S) of production processes. Substrate efficiency is calculated by formulas:

$$
\text { Substrate efficiency }(\%)=\frac{\text { So }-\mathrm{S}}{\text { So }} \times 100 \%
$$

\subsection{Data analysis}

Data processing were analyzed using analysis of variance (F test $5 \%$ ). If there is a significant effect on treatments, then continued using LSD test to detect differences between treatments.

\section{Results And Discussion}

\subsection{Fiber composition of materials during pretreatment and hydrolysis processes}

Based on Table 1, shows a decrease in the lignin content of corncob material, before delignification $12,74 \%$ to $2,99 \%$ after delignification. Lignin content in the sugarcane bagasse materials also decreased, before delignification $22,87 \%$ to $1,50 \%$ after delignification. Data analysis showed that the lignin content of corncob and bagasse material can not be eliminated completely through the process of delignification or pretreatment. Judoamidjojo et al. (1989) stated that the lignin is resistant to hydrolysis because of the aryl-alkyl and ester bond. The presence of difficult to degrade lignin content led to the formation of glucose becomes more difficult.

Table 1. Fiber composition analysis of corncob and sugarcane bagasse

\begin{tabular}{ccccc}
\hline \multirow{2}{*}{ Raw materials } & Fibers & \multicolumn{3}{c}{ Content (\%) } \\
\cline { 3 - 5 } & & Before delignification & $\begin{array}{c}\text { After } \\
\text { delignification }\end{array}$ & $\begin{array}{c}\text { Hydrolysis } \\
\text { residue }\end{array}$ \\
\hline \multirow{2}{*}{ Corncob } & Cellulose & 29,85 & 36,61 & 4,65 \\
& Hemicellulose & 32,67 & 11,17 & 1,33 \\
Sugarcane bagasse & Lignin & 12,74 & 2,99 & 2,71 \\
& Cellulose & 40,47 & 63,94 & 6,87 \\
& Hemicellulose & 17,35 & 7,67 & 0,47 \\
& Lignin & 22,87 & 1,50 & 1,33 \\
\hline
\end{tabular}

The content of the initial cellulose of corncob material $29,85 \%$ lower than sugarcane bagassel materials of $40,47 \%$. After the delignification process, there is an increase in the cellulose content of corncob and sugarcane bagasse materials respectively $36.61 \%$ and $63.94 \%$. The increase in cellulose content is caused by the increase in the specific surface area of cellulose, and hemicellulose dissolution in $\mathrm{NaOH}$. The increase in cellulose content of the material results of delignification followed by hemicellulose content decreased. There was a decrease in the hemicellulose content of corncob material from $32,67 \%$ to $11,17 \%$. There was also a decrease in the hemicellulose content of the sugarcane bagasse material from $17,35 \%$ to $7,67 \%$.

\subsection{Sugars and ethanol production during the hydrolysis and fermentation process}

Acid hydrolysis process is carried out using $\mathrm{HCl}$ and enzymatic hydrolysis using Aspergillus niger cultures with a density of $2 \times 10^{7} / \mathrm{ml}$ and Trichoderma viride with a density of $3 \times 10^{7} / \mathrm{ml}$. Total sugar content analysis results indicate the kind of corncob, the addition of culture A. niger produce total sugar of $11,80 \%$, higher than other treatments.

Table 2. Production of sugar and ethanol from substrate hydrolysis and fermentation of corncob and sugarcane bagasse

\begin{tabular}{|c|c|c|c|c|c|c|}
\hline Raw materials & Treatments & $\begin{array}{l}\text { Reducing } \\
\text { sugar (\%) }\end{array}$ & $\begin{array}{c}\text { Total sugar } \\
\text { initial } \\
(\%)\end{array}$ & $\begin{array}{l}\text { Total sugar } \\
\text { residue } \\
(\%)\end{array}$ & $\begin{array}{c}\text { Substrate } \\
\text { efficiency } \\
(\%)\end{array}$ & $\begin{array}{c}\text { Ethanol } \\
\text { content }(\%)\end{array}$ \\
\hline \multirow{4}{*}{ Corncob } & Witout fungus & $0,96 \mathrm{a}$ & $9,00 \mathrm{a}$ & $1,28 \mathrm{e}$ & $85,67 \mathrm{~b}$ & $4,19 \mathrm{a}$ \\
\hline & A. niger & $3,27 \mathrm{e}$ & $11,80 \mathrm{c}$ & $1,13 \mathrm{bc}$ & $90,35 \mathrm{~cd}$ & $6,30 \mathrm{~cd}$ \\
\hline & $\mathrm{T}$. viride & $2,49 \mathrm{c}$ & $10,60 \mathrm{bc}$ & $1,62 \mathrm{f}$ & $84,71 \mathrm{~b}$ & $5,04 \mathrm{abc}$ \\
\hline & A. niger $+T$. viride & $1,56 \mathrm{~b}$ & $10,20 \mathrm{ab}$ & $1,72 \mathrm{~g}$ & 83,13 a & $4,43 \mathrm{ab}$ \\
\hline \multirow{4}{*}{ Sugarcane bagasse } & Witout fungus & $1,03 \mathrm{a}$ & $10,50 \mathrm{bc}$ & $1,11 \mathrm{ab}$ & $89,43 \mathrm{c}$ & $4,37 \mathrm{ab}$ \\
\hline & A. niger & $2,92 \mathrm{~d}$ & $11,20 \mathrm{bc}$ & $1,18 \mathrm{~d}$ & $89,46 \mathrm{c}$ & $4,78 \mathrm{abc}$ \\
\hline & $\mathrm{T}$. viride & $3,99 \mathrm{f}$ & $16,90 \mathrm{e}$ & $1,07 \mathrm{a}$ & $93,67 \mathrm{e}$ & $6,83 \mathrm{~d}$ \\
\hline & A. niger $+T$. viride & $2,53 \mathrm{c}$ & $13,30 \mathrm{~d}$ & $1,16 \mathrm{~cd}$ & $91,26 \mathrm{~d}$ & $6,09 \mathrm{bcd}$ \\
\hline \multicolumn{2}{|c|}{ LSD 5\% } & 0,325 & 1,291 & 0,041 & 1,138 & 2,326 \\
\hline
\end{tabular}


Values followed by the same letter showed that not significant different by Least Significant Difference Test (LSD) at $5 \%$ level.

For the type of sugarcane bagasse, the addition of culture T. viride produce total sugar of $16,90 \%$, higher than the other treatments (Table 2). Average of all treatments using sugarcane bagasse materials produced higher total sugar than corncob, respectively $12,98 \%$ and $10,40 \%$. It is influenced by the initial cellulose content of sugarcane bagasse is higher than with corncob, so the total sugar content is higher. A high content of total sugar will result in high reducing sugar. This is because more sugar polymers are available, it will be the more sugar that can be reduced to a sugar monomers.

Reducing sugar content analysis results indicate the type of corncob material, the addition of culture A. niger produces reducing sugar of 3,27\%, higher than the other treatments (Table 2). Bioethanol research results conducted by Chen et al. (2007) that uses raw materials to the delivery of corncob cellubiase and cellulase enzymes from T. reesei and A. niger on hydrolysis process is capable of producing up to $6.22 \%$ reducing sugar. Reducing sugar content which can be caused by less than optimal results delignification of cellulose content is low, amounting to $36,61 \%$, while the results of the research by Sunarti et al. (2008) that cellulose content of corncob after delignification process by $44.36 \%$. If the cellulose content as substrate hydrolyis is low, the reducing sugar produced less than optimal. Reducing sugar content analysis results indicate the type of sugarcane bagasse material, the addition of culture T. viride produces reducing sugar of 3,99\%, higher than the other treatments (Table 2).

Substrate efficiency indicates the amount of sugar consumed during the fermentation process (Arnata et al., 2010). The higher value of substrate efficiency will decrease the residual sugar content. For the the type of corncob material, the addition of culture A. niger has a value of substrate efficiency of $90,35 \%$, higher than the other treatments, while the addition of culture A. niger $+\mathrm{T}$. viride has the lowest value of the substrate efficiency of $83.13 \%$ (Table 2). For the indicate the type of sugarcane bagasse material, the addition of culture T. viride has a value of substrate efficiency of $93,67 \%$, higher than the other treatments, while the treatments without fungus addition has the lowest substrate efficiency value of $89,43 \%$ (Table 2). Average of all treatments using sugarcane bagasse materials produce substrate efficiency value is higher than the corncob materials, respectively $90,95 \%$ and $85,96 \%$.

\subsection{Fermentation activity}

Ethanol production through fermentation using yeast Saccharomyces cereviciae in anaerobic condition for eight days. In anaerobic condition or no oxygen, yeast will make the process of anaerobic fermentation where sugar is available to be converted into ethanol and $\mathrm{CO}_{2}$. Khanal (2008) suggested that the anaerobic fermentation, organic substances catabolized without available oxygen which means there is no external electron acceptors but through the balance of internal oxidation-reduction reaction. Products generated during the process that electrons are released when organic matter breakdown. In the fermentation process, the substrate is only partially oxidized and produced only a little energy. At the time converted to pyruvic acid, glucose as a substrate to release electrons, but the electrons will then be taken by the pyruvate to ethanol.

Based on Figure 1 and Figure 2 shows the change in total sugars, ethanol content and $\mathrm{pH}$ value during fermentation in all treatments. During the fermentation process, total sugars decreased from 0 to 2 days, after which total sugars decreased relatively constant until 8 days. Decrease in total sugar content followed by an increase of ethanol content, it is due to the consumption of glucose by yeast to produce ethanol. Ethanol content increased on 2 days until 6 days, after which the ethanol content is relatively constant until the end of fermentation.

Judoamidjojo (1989) stated that the ethanol fermentation in anaerobic conditions using yeast, from one molecule of glucose to form two molecules of ethanol and $\mathrm{CO}_{2}$. So theoretically one gram of glucose will produce 0,51 grams of ethanol. The $\mathrm{pH}$ value af substrate decreased from the beginning to the end of the fermentation process. The $\mathrm{pH}$ decline associated with the production of organic acid during fermentation (Rehm and Reed, 1983).

The total sugars content during the fermentation process as a whole has decreased. Sugar as fermentation substrate in anaerobic condition used by S. cereviciae to produce ethanol. Therefore, the total sugar content of the substrate decreases with increasing fermentation time. Glucose as substrate fermentation is broken down into pyruvate through glycolysis and produces two molecules of ATP (Tao et al., 2005).

Total sugars significantly decreased occurred on 0 to 2 days. This suggests that the yeast $\mathrm{S}$. cerevisiae actively utilize glucose as a substrate fermentation to produce ethanol. After 2 days, the rate of decline in total sugar relatively slowly. The research result by Didu (2010) showed that the decrease in sugar concentration occurred more rapidly in the initial phase to enter the 18 hours, and then after the 18 hours the rate is relatively slow decline in sugar concentration. It can be caused by the accumulation of ethanol as a product of fermentation. Clark and Mackie (1984) stated that $1-2 \%$ ethanol at a concentration sufficient to inhibit the 
growth and the concentration of $10 \%$ may stop the growth of yeast. This is because ethanol is toxic to yeast, so that in most yeast, ethanol production will be halted at a concentration of $11-18 \%$.

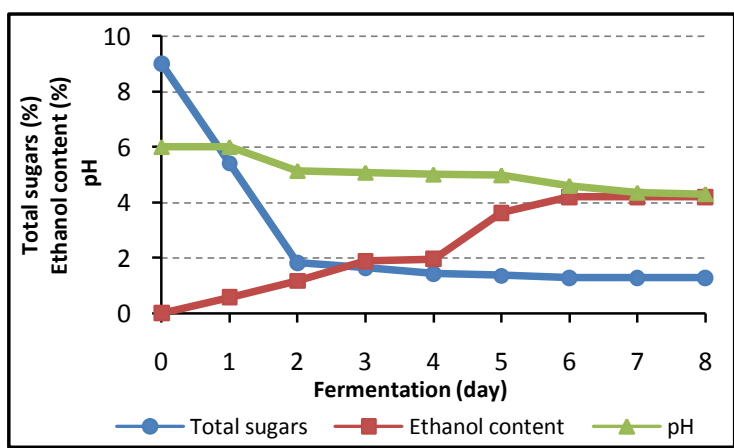

(a)

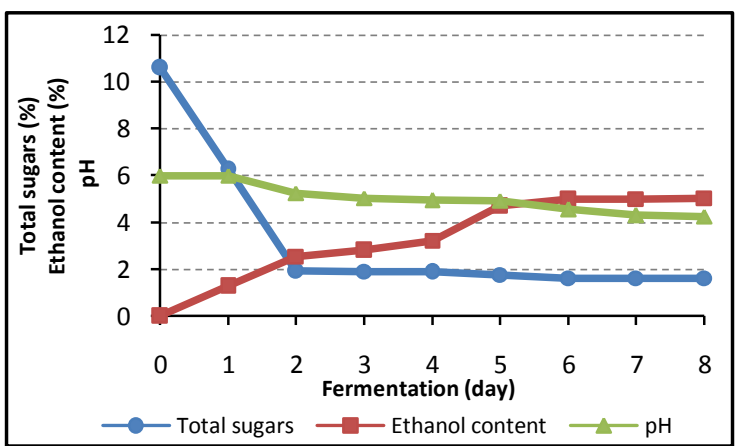

(c)

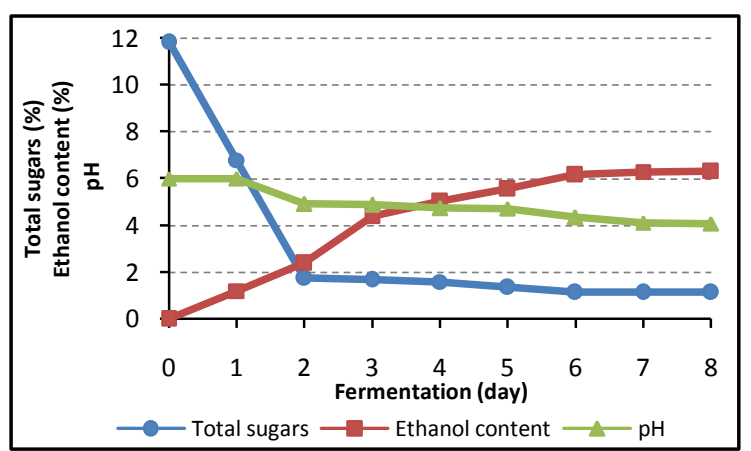

(b)

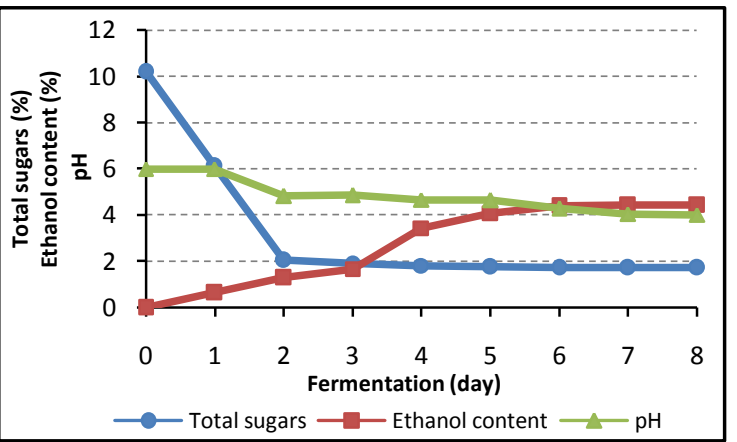

(d)

Figure 1. The changes in total sugars, ethanol content and $\mathrm{pH}$ value during fermentation on corncob materials with: (a) without the fungus addition, (b) the addition of A. niger, (c) the addition of T. viride, (d) the addition of A. niger and $\mathrm{T}$. viride.

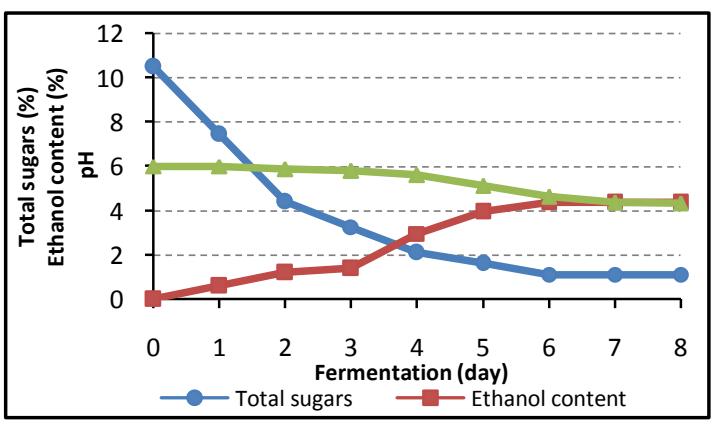

(a)

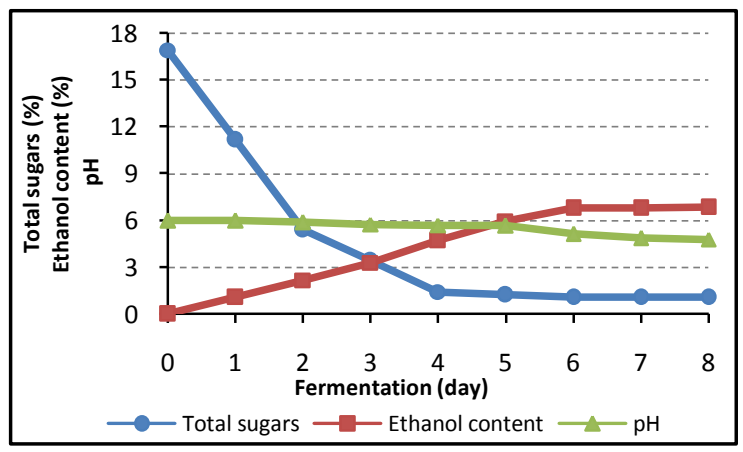

(c)

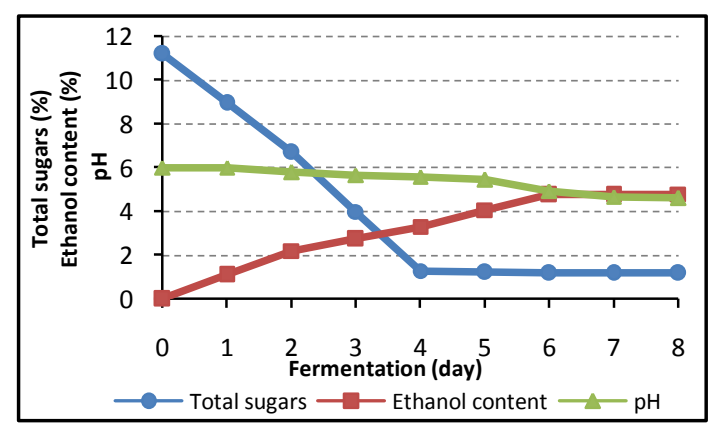

(b)

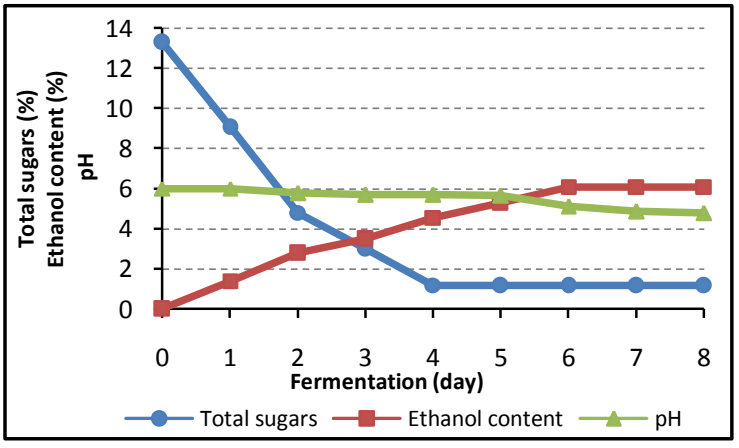

(d)

Figure 2. The changes in total sugars, ethanol content and $\mathrm{pH}$ value during fermentation on sugarcane bagasse materials with: (a) without the fungus addition, (b) the addition of A. niger, (c) the addition of T. viride, (d) the addition of $A$. niger and $T$. viride. 
The sugar content in the fermentation substrate remaining until the end of the fermentation process. This show is not all sugar in the substrate utilized by the yeast S. cerevisiae to produce ethanol. Wignyanto and Novita (2001) stated that most of the sugar is not converted due to the sugar concentration outside the cell is too high, causing differences in the concentration and osmotic pressure of the fluid between the environment and the resulting yeast cells plasmolisis events.

During the fermentation process, the ethanol content increased in all treatments until the end of fermentation. This suggests that the anaerobic conditions in the form of glucose fermentation substrate utilized by S. cerevisiae to form products such as ethanol. Prasad et al. (2006) stated that the anaerobic fermentation, glucose is converted to pyruvic acid through the EMP pathway. Pyruvic acid is converted to acetaldehyde by the enzyme pyruvate decarboxylase assistance and subsequently converted into alcohol with the help of the enzyme dehydrogenase.

For the type of corncob materials, the addition of culture A. niger has ethanol content of $6,30 \%$, higher than the other treatments, while treatment without fungus addition has lower ethanol content of $4,19 \%$ (Table 2 ). For the type of sugarcane bagasse materials, the addition of culture T. viride has ethanol content of $6,83 \%$, higher than the other treatments, while treatment without fungus addition has lower ethanol content of $4,37 \%$ (Table 2). Average of all treatments using sugarcane bagasse materials produce higher ethanol content than corncob materials, respectively $5,52 \%$ and $4,99 \%$.

\subsection{Bioethanol production}

Ethanol is derived from distillation process of fermentation substrates that have been separated by water. The volume of ethanol produced in the different treatment of each type of raw material and funfus culture For the type of corncob materials, the addition of culture A. niger produce ethanol at $282,3 \mathrm{ml} / \mathrm{kg}$, higher than the other treatments, while treatment without fungus addition has lower ethanol yield at $185,1 \mathrm{ml} / \mathrm{kg}$ (Table 2). For the type of sugarcane bagasse materials, the addition of culture T. viride produce ethanol at $299,2 \mathrm{ml} / \mathrm{kg}$, higher than the other treatments while treatment without fungus addition has lower ethanol yield at $188,6 \mathrm{ml} / \mathrm{kg}$ (Table 2). Average of all treatments using sugarcane bagasse materials produce higher ethanol yield than corncob materials, respectively $258,2 \mathrm{ml} / \mathrm{kg}$ and $237,3 \mathrm{ml} / \mathrm{kg}$. Potential ethanol yield from raw material bagasse and corncob respectively of $279 \mathrm{ml} / \mathrm{kg}$ and $358 \mathrm{ml} / \mathrm{kg}$ (Kuhad and Singh, 1993). This suggests that ethanol yield that have been obtained can still be improved.

Table 3. Distilled ethanol production

\begin{tabular}{cccc}
\hline Raw materials & Treatments & Ethanol yield $(\mathrm{ml} / \mathrm{kg})$ & Spesific gravity \\
\hline \multirow{3}{*}{ Corncob } & Witout fungus & 185,1 a & 0,830 \\
& A. niger & 282,3 cd & 0,826 \\
& T. viride & 259,0 bcd & 0,830 \\
& A. niger + T. viride & 222,8 abc & 0,829 \\
\hline Sugarcane bagasse & Witout fungus & 188,6 a & 0,829 \\
& A. niger & 253,3 bc & 0,826 \\
& T. viride & 299,2 d & 0,822 \\
\hline & A. niger + T. viride & 291,7 cd & 0,825 \\
\hline
\end{tabular}

Values followed by the same letter showed that not significant different by Least Significant Difference Test (LSD) at 5\% level, $\mathrm{ns}=$ not significant.

Based on Figure 3 shows that in the treatment without the addition of fungus, the ethanol yield from corncos and sugarcane bagasse is lower than the other treatments. In the addition of culture A. niger, the ethanol yield from corn cob material is higher than sugarcane bagasse. In the addition of culture T. viride, ethanol yield from sugarcane bagasse material is higher than corncos. While on treatment the addition of culture A. niger $+\mathrm{T}$. viride, ethanol yield from sugarcane bagasse material is higher than corncob.

Effectiveness of fungus in increasing the ethanol yield from lignocellulosic materials depends on the activity of enzymes produced. A. niger produces more hemicellulase enzyme complex that can hydrolyze hemicellulose into glucose (Pham et al., 2010). While the advantages of T. viride compared to other types of fungus are capable of producing a complete cellulolytic enzymes and also produce enzymes xyloglukanolitik (Tribak et al., 2002). 


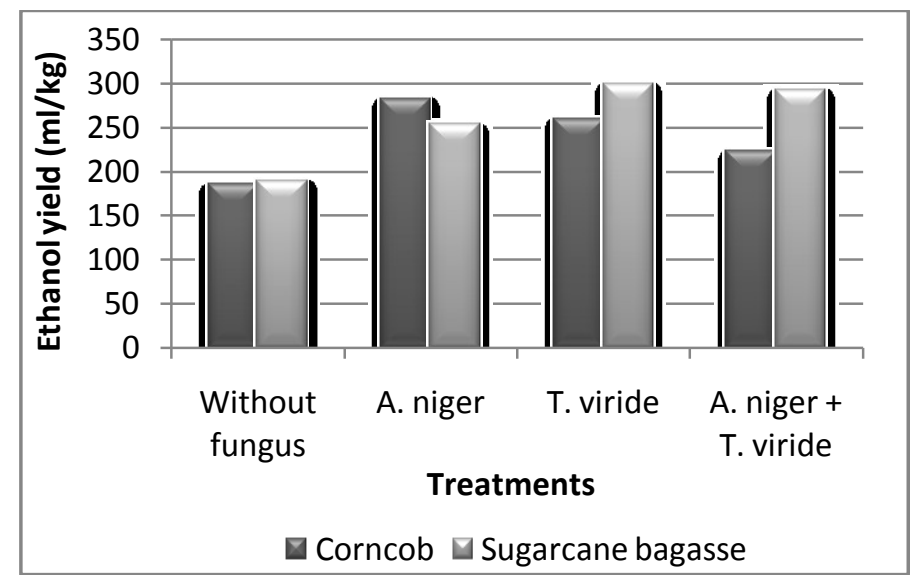

Figure 3. Volumes of ethanol at various treatments.

The $\mathrm{pH}$ value measurement results on all treatments showed a decrease. It is related to the consumption of glucose through the process of glycolysis and accumulation of organic acids compounds formed during fermentation, including acetic acid, lactic acid and pyruvic acid. Rehm and Reed (1983) states that the acid formed as a by-product of ethanol fermentation processes such as acetic acid, pyruvic acid and other organic acids play a major role in the decrease in $\mathrm{pH}$. Low $\mathrm{pH}$ values at the end of fermentation showed that the accumulation of acid and accumulate more and more, due to the S.cerevisiae cells that can not convert the acids are mainly pyruvic acid into ethanol. Medium conditions such as $\mathrm{pH}$ has a great influence on the growth and activity of microorganisms.

Table 4. The average of $\mathrm{pH}$ value of the end of fermentation substrate on various treatments.

\begin{tabular}{lccc}
\hline \multirow{2}{*}{ Treatments } & \multicolumn{3}{c}{$\mathrm{pH}$ value } \\
\cline { 2 - 4 } & Corncob & Sugarcane bagasse & Average \\
\hline Without fungus addition & 4,293 & 4,318 & 4,305 \\
A. niger & 4,074 & 4,613 & 4,343 \\
T. viride & 4,256 & 4,778 & 4,517 \\
A. niger + T. viride & 4,017 & 4,778 & 4,397 \\
\hline
\end{tabular}

Based on Table 4 shows that only by using acid hydrolysis (without the fungus addition) will result in a lower $\mathrm{pH}$ value than the cellulolytic hydrolysis using a fungus culture. Chandel et al. (2007) stated that the use of acid saccharification is not specific. In addition to glucose, the acid saccharification can produce byproducts such as furan compounds, phenolic, and acetic acid. Acidic byproducts that if not removed can inhibit the fermentation process by lowering the $\mathrm{pH}$ value is lower.

\section{Conclusion}

The addition of culture Aspergillus niger and Trichoderma viride on the hydrolysis of corncob and sugarcane bagasse effect on increasing of sugar production, ethanol yield and substrate efficiency. In the treatment of the raw material of corncob with variations the addition of fungus culture, the addition of Aspergillus niger is the best treatment combination that produces a total sugar content of $11,80 \%$ and the ethanol yield of $282,3 \mathrm{ml} / \mathrm{kg}$ with substrate efficiency of $90,35 \%$. While the sugarcane bagasse materials, the addition of Trichoderma viride is the best treatment combination that produces a total sugar content of $16,90 \%$ and the ethanol yield of $299,2 \mathrm{ml} / \mathrm{kg}$ with substrate efficiency of $93,67 \%$. Production of bioethanol from sugarcane bagasse materials at an average of all the fungus additional treatments produce higher yields than corn cobs with an average ethanol yield of $258,2 \mathrm{ml} / \mathrm{kg}$.

\section{References}

[1]. A.A. Juwaied., A.A.H. Al-amiery, Z. Abdumuniem and U. Anaam, Optimization of cellulase production by Aspergillus niger and Tricoderma viride using sugar cane waste, Journal of Yeast and Fungal Research, 2(2), 2011, 19-23

[2]. A.K Chandel, E.S. Chan., R. Rudravaram, M.L. Narasu, L.V. Rao and P. Ravindra, Economics and environmental impact of bioethanol production technologies: An appraisal, Biotechnology and Molecular Biology Review. 2(1), 2007, 14-32

[3]. E.M. Clark, Molecular characterization of side-chain cleaving hemicellulaces of Trichoderma reesei, Academic Dissertation, Technical Reserach Centre of Finland, 1996

[4]. F. Tao, J.Y. Miao, G.Y. Shi and K.C. Zhang, Ethanol Fermentation by an acid tolerant Zymomonas mobilis under non-sterilized condition, Journal Process Biochemistry, 40, 2005, 183-187

[5]. H.J. Rehm and G. Reed, Biotechnology (Microbial Fundamental (I). Verlag Chemi Gmbh, Weinheim, 1983) 
[6]. M. Tribak, M, J.A.Ocampo and I. Garcia-Romera, Production of xyloglucanolytic enzymes by Trichoderma viride, Paecilomyces farinosus, Wardomyces inflatus, and Pleurotus ostreatus. Mycologia, 3, 2002 404-410

[7]. M.L. Chen,. Xia and P. Xue, Enzymatic hydrolysis of corncob and etanol production from cellulosic hydrolysate, Journal International Biodeterioration \& Biodegradation, 59, 2007, 85-89

[8]. M.P. Prasad, R. Sethi, M. Tamiiarasan and K.S. Subha, Production of bioethanol using various agricultural raw materials by two step enzymatic process. Journal of Advanced Biotech, 2009, 41-43

[9]. N. Didu, Produksi bioetanol dari sirup glukosa ubi jalar (Ipomoea batatas L) secara fed batch dengan menggunakan Saccharomyces cerevisiae. Pascasarjana IPB, Bogor, 2010

[10]. R. Muthuvelayudham and T. Viruthagiri, Optimizaton and Modeling of Cellulase Protein from Trichoderma ressei Rut C30 Using Mixed Substrate. African Journal of Biotechnology, 6 (1), 2007, 41-46

[11]. R.C. Kuhad and A. Singh, Lignocellulosic biotechnology: current and future prospects, Journal Biotechnology. 13, 1993, 151-172

[12]. S. Prasad, A. Sighn and H.C. Jochi, Ethanol as an alternatif fuel from agriculture, industrial, urban residues. Journal Resources, Conservation and Recycling. 50, 2006, 1-39

[13]. S. Wignyanto, and Novita, Pengaruh konsentrasi gula reduksi sari hati nanas dan inokulum Saccharomyces cerevisiae pada fermentasi etanol, Jurnal Teknologi Pertanian, 2(1), 2001, 68-77

[14]. S.J. Patel, R. Onkarappa and K.S. Shobha, Study of ethanol production from fungal pretreated wheat and rice straw. The Internet Journal of Microbiology, 4(1), 2007, 1-6

[15]. T.H. Pham, J.G. Berrin, E. Record, K.A. To and J. Sigoillot, Hydrolysis of softwood by Aspergillus mannanase: Role of a carbohydrate-binding module, Journal of Biotechnology, 148, 2010, 163-170. 